\title{
Do pediatric medicines induce topographic changes in dental enamel?
}

\section{Adílis Kalina ALEXANDRIA Nicolli de Araujo MECKELBURG Ursula Tavares PUETTER Jordan Trugilho SALLES Ivete Pomarico Ribeiro de SOUZA Lucianne Cople MAIA}

Universidade Federal do Rio de Janeiro UFRJ, School of Dentistry, Department of Pediatric Dentistry and Orthodontics, Rio de Janeiro, RJ, Brazil.

Declaration of Interests: The authors certify that they have no commercial or associative interest that represents a conflict of interest in connection with the manuscript.

\section{Corresponding Author:}

Lucianne Cople Maia

E-mail: rorefa@terra.com.br

DOI: 10.1590/1807-3107BOR-2016.vol30.0011

Submitted: Oct 28, 2014

Accepted for publication: Jul 29, 2015

Last revision: Aug 31, 2015
Abstract: The purpose of the present study was to evaluate the effect of common pediatric liquid medicines on surface roughness and tooth structure loss and to evaluate the $\mathrm{pH}$ values of these medicines at room and cold temperatures in vitro. Eighty-four bovine enamel blocks were divided into seven groups $(n=12)$ : G1-Alivium ${ }^{\circledR}$, G2-Novalgina ${ }^{\circledR}$, G3-Betamox ${ }^{\circledR}, \quad$ G4-Clavulin ${ }^{\circledR}, \quad$ G5-Claritin ${ }^{\circledR}, \quad$ G6-Polaramine ${ }^{\circledR}$ and G7-Milli-Q water (negative control). The $\mathrm{pH}$ was determined and the samples were immersed in each treatment 3x/day for $5 \mathrm{~min}$. 3D non-contact profilometry was used to determine surface roughness (linear $\mathrm{Ra}$, volumetric Sa) and the Gap formed between treated and control areas in each block. Scanning electron microscopy (SEM) and energy dispersive spectrometry (EDS) were also performed. The majority of liquid medicines had $\mathrm{pH} \leq 5.50$. G1, G4, and G5 showed alterations in Ra when compared with G7 ( $p<0.05)$. According to Sa and Gap results, only G5 was different from G7 ( $p<0.05)$. Alteration in surface was more evident in G5 SEM images. EDS revealed high concentrations of carbon, oxygen, phosphorus, and calcium in all tested groups. Despite the low $\mathrm{pH}$ values of all evaluated medicines, only Alivium ${ }^{\circledR}$, Clavulin $^{\circledR}$, and Claritin ${ }^{\circledR}$ increased linear surface roughness, and only Claritin ${ }^{\circledR}$ demonstrated the in vitro capacity to produce significant tooth structure loss.

Keywords: Dental Enamel; Administration, Oral; Pharmaceutical Preparations; Acidity; Topography.

\section{Introduction}

Medicines in liquid form are widely used for children because they facilitate intake. ${ }^{1,2,3}$ However, some of the inactive agents used in pediatric liquid medications can cause damage to dental tissues because of their low $\mathrm{pH} .{ }^{3}$ Some medicines have acid in their compositions in order to preserve their chemical stability and control their tonicity. ${ }^{4}$

Certain properties of acidic products in general may be related to the loss of surface structure of dental enamel: low endogenous $\mathrm{pH}$, high titratable acidity, and minimal quantities of minerals such as calcium or phosphate, in their compositions. ${ }^{3,5,6,7,8}$ Acidic medications may cause dental erosion with loss of dental tissue. ${ }^{1,4}$ Besides the presence of acids in some children's medications, other factors may also be related to changes in the surface morphology of dental enamel: high frequency of medication intake, bedtime consumption, high viscosity, and reduction in salivary flow. ${ }^{3,5}$ 
Many oral liquid medicines are usually recommended for sick children for long periods, and in cases of chronic diseases, they are administered daily. In vitro studies have shown that an acidic medication may reduce enamel hardness, ${ }^{9,10,11}$ but, to the best of our knowledge, the influence of pediatric oral liquid medicines on enamel topography has not been studied yet. For this reason, the purpose of this in vitro study was to evaluate the effect of common pediatric liquid medicines on surface roughness and tooth structure loss and to evaluate the $\mathrm{pH}$ values of these medicines at room and cold temperatures.

\section{Methodology}

\section{Pediatric medicines and $\mathrm{pH}$ analysis}

The pediatric medicines used in this study were two analgesics - Alivium ${ }^{\circledR}$ (Mantecorp, São Paulo, Brazil) and Novalgina ${ }^{\circledR}$ (Sanofi-Aventis, Paris, France); two antibiotics - Betamox ${ }^{\circledR}$ (Atral, Castanheira do Ribatejo, Portugal) and Clavulin ${ }^{\circledR}$ (GlaxoSmithKline, Brentford, United Kingdom); and two antihistamines - Claritin ${ }^{\circledast}$ (Schering-Plough, USA) and Polaramine ${ }^{\circledR}$ (Mantecorp, São Paulo, Brazil) (Table 1).

The $\mathrm{pH}$ values of the selected medicines at cold and room temperatures were determined using a pH meter (Orion 261S, Thermo Fisher Scientific Inc., Waltham, USA). After equipment calibration, three samples of each pediatric medicine were analyzed with $\mathrm{pH}$ electrodes. The average of the three measurements was used as the $\mathrm{pH}$ value (Table 1).

\section{Specimen preparation}

Sound bovine incisor crowns were cut using a water-cooled diamond saw (Bühler, Uzwil, Switzerland) to obtain enamel blocks $(4 \times 4 \times 2 \mathrm{~mm})$. These blocks were fixed with wax in an acrylic device to polish the enamel surface: 600- and 1200-grit silicon carbide papers (Extec Corp., Enfield, USA), followed by a 1- $\mu \mathrm{m}$ diamond abrasive slurry (Extec Corp., Enfield, USA) and washed ultrasonically in Milli-Q water (Merck Millipore, Darmstadt, Germany). Baseline surface microhardness (SMH) was measured using a microhardness tester (HVS-1000, Time Group Inc., Beijing, China) with a Knoop diamond under a 50-g load for $5 \mathrm{~s}$, and five indentations spaced $100 \mu \mathrm{m}$ from each other were made at the center of the enamel surface to select the sample. A total of 84 blocks (mean $341.59 \pm 34.15 \mathrm{~kg} / \mathrm{mm}^{2}$ ) were selected for the present study and randomly divided into seven groups $(\mathrm{n}=$ 12): $\mathrm{G} 1=$ Alivium $^{\circledR}, \mathrm{G} 2=$ Novalgina $^{\circledR}, \mathrm{G} 3=$ Betamox $^{\circledR}$, G4 = Clavulin ${ }^{\circledR}$, G5 $=$ Claritin $^{\circledR}$, G6 $=$ Polaramine $^{\circledR}$, and G7 = Milli-Q water (experimental control).

An acid-resistant nail varnish was used to divide the enamel surface into two distinct areas: 1) a sound window (unexposed area) - the right side of the enamel surface was covered with acid-resistant nail varnish (self-positive control); and 2) an experimental window (exposed area) - the left side was not covered.

\section{Experimental protocols}

Twelve blocks from each group were immersed in pediatric liquid medicines three times a day for 5 $\min$ ( $15 \mathrm{~mL}$ per block) for 7 days. After treatment, the specimens were rinsed with deionized water $(5 \mathrm{~s})$ and

Table 1. Parameters of the pediatric medicines and control.

\begin{tabular}{|c|c|c|c|c|c|}
\hline \multicolumn{6}{|c|}{ Characteristics } \\
\hline Pediatric medicine & Active ingredient & Concentration & Trademark & $\begin{array}{l}\mathrm{pH} \text { at cold } \\
\text { temperature }\end{array}$ & $\begin{array}{l}\mathrm{pH} \text { at room } \\
\text { temperature }\end{array}$ \\
\hline G1 (Alivium ${ }^{\circledR}$ ) & Ibuprofen & $30 \mathrm{mg} / \mathrm{mL}$ & Mantecorp & 4.37 & 3.70 \\
\hline G2 (Novalgina ${ }^{\circledR}$ ) & Dipyrone & $50 \mathrm{mg} / \mathrm{mL}$ & Sanofi-aventis & 7.25 & 6.98 \\
\hline G3 $\left(\right.$ Betamox $\left.^{\circledR}\right)$ & Amoxicillin and Clavulanic Acid & $250 \mathrm{mg} / 5 \mathrm{~mL}+62.5 \mathrm{mg} / 5 \mathrm{~mL}$ & Atral & 5.83 & 4.64 \\
\hline G4 (Clavulin $\left.{ }^{\circledR}\right)$ & Amoxicillin and Clavulanic Acid & $250 \mathrm{mg} / 5 \mathrm{~mL}+62.5 \mathrm{mg} / 5 \mathrm{~mL}$ & SmithKline Beecham & 5.48 & 5.50 \\
\hline G5 $\left(\right.$ Claritin $\left.^{\circledR}\right)$ & Loratadine & $1 \mathrm{mg} / \mathrm{mL}$ & Schering-Plough & 3.85 & 2.10 \\
\hline G6 (Polaramine ${ }^{\circledR}$ ) & Dexchlorpheniramine maleate & $2 \mathrm{mg} / 5 \mathrm{~mL}$ & Mantecorp & 6.72 & 6.27 \\
\hline G7 (Milli-Q water) & - & - & - & 7.01 & 6.99 \\
\hline
\end{tabular}


transferred into artificial saliva. All pediatric medicines were stored at $7^{\circ} \mathrm{C}$, but removed $5 \mathrm{~min}$ before the treatment period. After block immersion, they were returned to the refrigerator until new treatment.

Two artificial saliva solutions were prepared to simulate the oral environment and the $\mathrm{pH}$ changes that occur during the day, according to Queiroz et al., ${ }^{12}$ with some modifications. The first solution consisted of $0.05 \mathrm{~mol} / \mathrm{L}$ acetate buffer, $1.28 \mathrm{mmol} / \mathrm{L} \mathrm{Ca}, 0.74 \mathrm{mmol} / \mathrm{L}$ $\mathrm{P}$, and $0.03 \mu \mathrm{g} \mathrm{F} / \mathrm{mL}$ with $\mathrm{pH} 5.0$ for $2 \mathrm{~h}$ ( $50 \mathrm{~mL}$ per block); and the second one contained $0.1 \mathrm{~mol} / \mathrm{L}$ Tris buffer, $1.5 \mathrm{mmol} / \mathrm{L} \mathrm{Ca}, 0.9 \mathrm{mmol} / \mathrm{L} \mathrm{P}, 150 \mathrm{mmol} / \mathrm{L} \mathrm{KCl}$, and $0.05 \mu \mathrm{g} \mathrm{F} / \mathrm{mL}$ with $\mathrm{pH} 7.0$ for $22 \mathrm{~h}$ ( $25 \mathrm{~mL}$ per block).

The experimental protocol consisted of three periods of immersion in pediatric medicines and four periods in artificial saliva per day: $1^{\text {st }}$ period $-5 \mathrm{~min}$ in pediatric medicines; $2^{\text {nd }}$ period $-6 \mathrm{~h}$ in artificial saliva ( $\left.\mathrm{pH} 7.0\right)$; $3^{\text {rd }}$ period $-2 \mathrm{~h}$ in artificial saliva $(\mathrm{pH} 5.0) ; 4^{\text {th }}$ period -5 min in pediatric medicines; $5^{\text {th }}$ period $-8 \mathrm{~h}$ in artificial saliva ( $\mathrm{pH} 7.0) ; 6^{\text {th }}$ period -5 min in pediatric medicines; and $7^{\text {th }}$ period $-8 \mathrm{~h}$ in artificial saliva ( $\mathrm{pH} 7.0$ ).

The experiment was carried out at $37^{\circ} \mathrm{C}$. On the $4^{\text {th }}$ day, the artificial saliva solutions were replaced with fresh ones in order to avoid oversaturation.

\section{D non-contact profilometry}

The surface topography of the specimens was analyzed by a3D profilometer (Nanovea PS50 Optical, NANOVEA Inc., Irvine, USA). The measurements of capture were performed with a chromatic confocal sensor with a white light axial source at a scan velocity of $2 \mathrm{~mm} / \mathrm{s}$ and with a refractive index of 10,000.

3D non-contact profilometry was used to determine the primary outcome: tooth structure loss, i.e., the gap between the experimental and control areas (Gap) in each group; and the secondary outcome: surface roughness - linear surface roughness ( $\mathrm{Ra}$ ) and volumetric surface roughness (Sa). All comparisons between the exposed and unexposed areas of enamel were performed after the removal of the acid-resistant nail varnish.

The Gap was calculated from the step height difference between the unexposed and exposed enamel surfaces in each block; three linear measurements were made involving the unexposed and exposed areas. All measurements were done in triplicate, and the mean values were used to represent the final result of the surface profile.

To determine $\mathrm{Ra}$, three linear measurements (one vertical, one horizontal and one transversal) were performed in each area (experimental window or sound window) of the enamel specimen. The average of these three linear measurements was used to determine Ra1 (surface linear roughness in the sound window) and Ra2 (surface linear roughness in the experimental window), and the Ra value for all groups was calculated as $\mathrm{Ra}=\mathrm{Ra} 1-\mathrm{Ra} 2$.

Also, three scan areas $(200 \mu \mathrm{m} \times 200 \mu \mathrm{m})$ were obtained for each block in the sound and experimental window. The average of these three areas was used to determine Sa1 (surface roughness in the sound window) and Sa2 (surface roughness in the experimental window); and the Sa value for all groups was calculated as $\mathrm{Sa}=\mathrm{Sa} 1-\mathrm{Sa} 2$.

\section{Scanning Electron Microscopy (SEM) and Energy Dispersive Spectrometry (EDS)}

Three enamel blocks from each group were randomly selected and prepared for EDS and SEM under a scanning electron microscope (6460LV, JEOL, Tokyo, Japan). The blocks were mounted onto stubs with double-faced carbon tape and analyzed by EDS. EDS was performed to assess the mineral content of the enamel, identifying the chemical elements on its surface before and after the experimental protocol. Therefore, it was possible to compare the chemical elements found in treated (exposed) and untreated (unexposed) areas. This analysis was performed with a Kontron automatic image analyzer system, and the total area of the block was evaluated. The results were represented by the mean of the measured values.

After EDS, the samples were covered with a $30 \mu$ m gold layer and SEM was performed to assess the topography of the enamel surface. The specimens were examined under the same scanning electron microscope at $20 \mathrm{kV}$ in low vacuum mode (45 Pa) and the backscattered electrons (BSE) were analyzed. Initially, the specimens were analyzed under a panoramic view (500X) to observe the interface between the windows (sound and experimental); photomicrographs of the most representative areas of each group were obtained at 1000X and 5000X magnification to observe any changes in more detail. 


\section{Statistical analysis}

The normal distribution of the data was checked for all tested variables, using the Shapiro Wilk test. A Student's paired t-test was used to compare Ra1 and Ra2 and Sa1 and Sa2. Differences in Ra and Sa among all treatment groups were tested with the Kruskal-Wallis test, followed by the Mann-Whitney test. One-way analysis of variance (one-way ANOVA), followed by a post-hoc test (Tukey's test), was used for Gap analysis. The SPSS software version 22.0 (IBM, Armonk, USA) was used for the statistical analysis. The significance level was set at 5\%.

\section{Results}

Table 1 shows the $\mathrm{pH}$ values of pediatric liquid medicines at room and cold temperatures. The $\mathrm{pH}$ values of pediatric medicines at room temperature were lower than at cold temperature. G1 and G5 presented the lowest $\mathrm{pH}$ values.

The results of 3D non-contact profilometry are summarized in Table 2 with mean $\mathrm{Ra}, \mathrm{Sa}$, and Gap for all groups. All pediatric medicines produced a significant alteration in surface roughness ( $R a$ and Sa) values after 7 days $(p<0.05)$. These alterations were evidenced when the images of the sound and experimental areas were compared (Figure 1).

The group treated with Claritin ${ }^{\circledast}$ presented the worst $\mathrm{Ra}$ and Sa values, being statistically different from the negative control $(\mathrm{p}<0.05)$. Clavulin ${ }^{\circledR}$, Betamox $^{\circledast}$, and Alivium ${ }^{\circledR}$ also showed statistical differences in Ra value when compared with the negative control $(p<0.05)$ (Table 2). Claritin ${ }^{\circledR}$ and
Clavulin ${ }^{\circledast}$ showed the worst alteration in surface roughness (Sa value) when compared with the negative control $(p<0.05)$ (Table 2).

When differences in Gap values were evaluated between the groups, only Claritin ${ }^{\circledast}$ presented a statistically significant tooth structure loss when compared with the negative control $(\mathrm{p}<0.05)$, but there was a similar trend among Claritin ${ }^{\circledR}$, Clavulin $^{\circledR}$, Polaramine ${ }^{\circledR}$, and Alivium ${ }^{\circledR}$ since there was no statistical difference between them $(p>0.05)$. (Table 2).

Figure 1 shows only a change in surface roughness in some groups (Novalgina ${ }^{\circledR}$, Polaramine ${ }^{\circledR}$ and Milli-Q water), while in others, such as Claritin ${ }^{\circledR}$, the loss of tooth structure was evident in the exposed area. The same can be observed in the images obtained by SEM (Figure 2). The images of the negative control showed few signs of alteration; on the other hand, Claritin ${ }^{\circledR}$ produced the worst alterations in enamel topography, causing loss of enamel structure (e.g., erosion).

The images of G1, G3, G4 and G5 showed that the enamel surfaces appeared to be more porous than the images of groups G2, G6 and G7.

The chemical analysis, made with EDS, revealed the presence of carbon, oxygen, sodium, phosphorus, calcium, chlorine, and aluminum. Exposed and unexposed areas retained high rates of carbon, oxygen, phosphorus, and calcium. In addition, it was possible to observe that calcium and phosphorus concentrations increased in exposed areas in all groups except for the group treated with Polaramine ${ }^{\circledast}$. The other elements had almost the same rates when compared to the unexposed and exposed areas (Table 3).

Table 2. Median (minimum/maximum value - $\mu \mathrm{m}$ ) of surface roughness (Ra and Sa) and Media ( $\mu \mathrm{m}$ ) of Gap \pm standard deviation between the unexposed and exposed enamel surface of enamel specimen groups.

\begin{tabular}{|c|c|c|c|}
\hline \multicolumn{4}{|c|}{ 3D non-contact profilometry results ( $\mu \mathrm{m})$} \\
\hline Pediatric medicine & $\mathrm{Ra}$ & $\mathrm{Sa}$ & Gap \\
\hline G1 (Alivium ${ }^{\circledR}$ ) & $-0.08(-0.24 / 0.03) b, c$ & $-0.15(-0.76 / 0.09) a, b, c$ & $4.26 \pm 1.90 a, b$ \\
\hline G2 $\left(\right.$ Novalgina $\left.^{\circledR}\right)$ & $-0.02(-0.17 / 0.04) a, b, c$ & $-0.04(-0.21 / 0.06) a, c$ & $2.65 \pm 1.30 a$ \\
\hline G3 $\left(\right.$ Betamox $\left.^{\circledR}\right)$ & $-0.04(-0.10 / 0.01) b, c$ & $-0.10(-0.47 / 0.01) a, c$ & $3.00 \pm 1.36 a$ \\
\hline G4 (Clavulin $\left.{ }^{\circledR}\right)$ & $-0.11(-0.38 /-0.01) b, c$ & $-0.15(-0.46 / 0.03) b, c$ & $4.07 \pm 2.00 a, b$ \\
\hline G5 (Claritin $\left.{ }^{\circledR}\right)$ & $-0.17(-0.28 / 0.05) b$ & $-0.53(-1.65 /-0.10) b$ & $5.18 \pm 1.26 b$ \\
\hline G6 (Polaramine ${ }^{\circledR}$ ) & $-0.02(-0.17 / 0.13) a, c$ & $-0.09(-0.37 /-0.02) a, c$ & $3.40 \pm 1.85 a, b$ \\
\hline G7 (Milli-Q water) & $0.07(0.00 / 0.29) a$ & $0.04(-0.08 / 0.14) a$ & $2.20 \pm 1.18 a$ \\
\hline
\end{tabular}

Means followed by distinct letters are statistically different $(p<0.05)$. For Ra and Sa analysis (Kruskall-Wallis test followed by Mann-Whitney test); For Gap analysis (One-way ANOVA followed by Tukey test). 

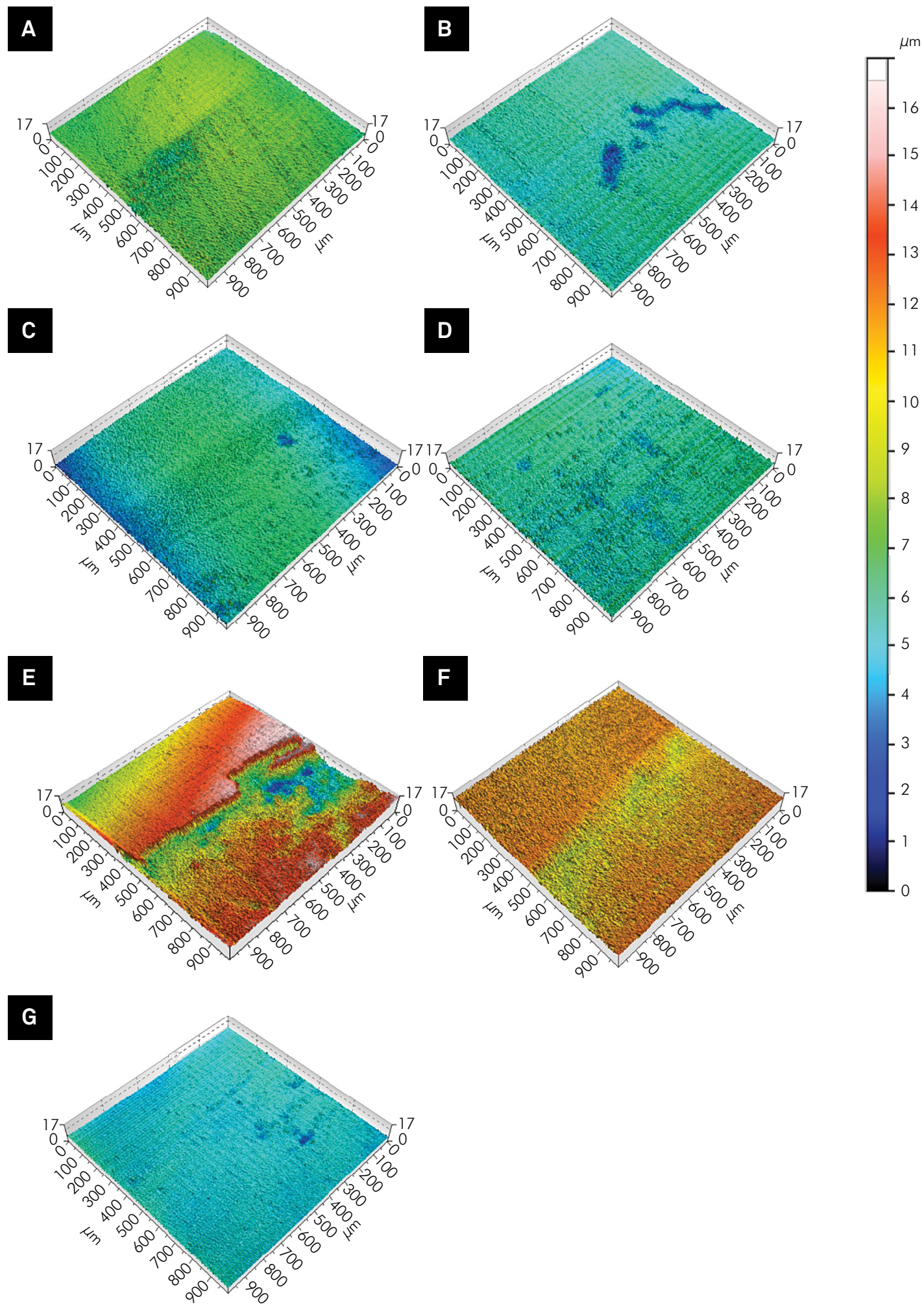

Figure 1.3D profilometry scheme representation of enamel surfaces after treatment and $\mathrm{pH}$ cycling. left - sound window (unexposed area) and right-experimental window (exposed area). (A) G1: Alivium ${ }^{\circledR}$, (B) G2: Novalgina ${ }^{\circledR}$, (C) G3: Betamox ${ }^{\circledR}$, (D) G4: Clavulin ${ }^{\circledR}$, (E) G5: Claritin ${ }^{\circledR}$, (F) G6: Polaramine ${ }^{\circledR}$, and (G) G7: Milli-Q water (negative control). 

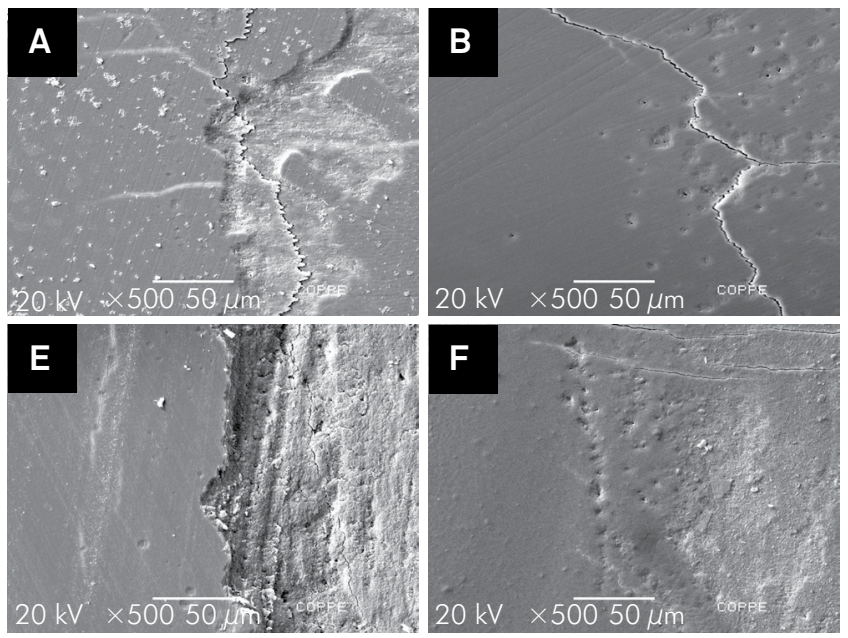
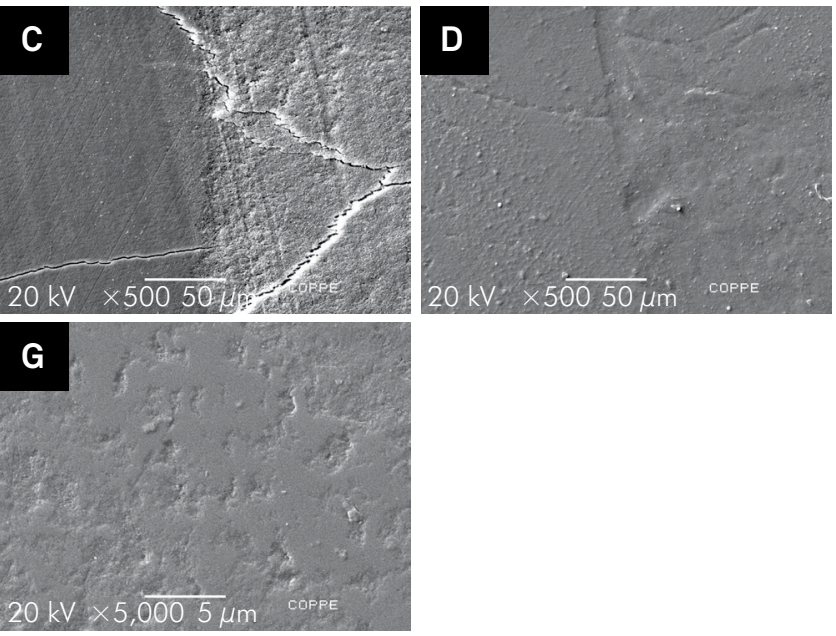

Figure 2. SEM images of enamel surfaces after treatment and $\mathrm{pH}$ cycling at 500X. Photomicrographs of the interface: left - sound window (unexposed area) and right-experimental window (exposed area). (A) G1: Alivium ${ }^{\circledR}$, (B) G2: Novalgina $^{\circledR}$, (C) G3: Betamox ${ }^{\circledR}$, (D) G4: Clavulin ${ }^{\circledR}$, (E) G5: Claritin ${ }^{\circledR}$, (F) G6: Polaramine ${ }^{\circledR}$, and (G) G7: Milli-Q water (negative control).

Table 3. Mean (\%) of EDS analysis of surface of enamel blocks, chemical elements are shown according to the treatments and area (unexposed or exposed).

\begin{tabular}{|c|c|c|c|c|c|c|c|c|c|}
\hline Groups & Evaluated area & C & 0 & $\mathrm{Na}$ & $\mathrm{Mg}$ & $\mathrm{Al}$ & $P$ & $\mathrm{Cl}$ & $\mathrm{Ca}$ \\
\hline \multirow[t]{2}{*}{ G1 Alivium ${ }^{\circledR}$} & Unexposed & 76.96 & 9.65 & 0.15 & - & 0.94 & 4.50 & 0.14 & 7.67 \\
\hline & Exposed & 62.62 & 15.77 & 0.18 & - & 0.48 & 7.21 & 0.16 & 13.59 \\
\hline \multirow[t]{2}{*}{ G2 Novalgina ${ }^{\circledR}$} & Unexposed & 55.83 & 23.95 & 0.22 & - & 0.58 & 7.24 & 0.21 & 11.97 \\
\hline & Exposed & 50.51 & 26.34 & 0.39 & - & 0.28 & 8.54 & 0.21 & 13.73 \\
\hline \multirow[t]{2}{*}{ G3 Betamox ${ }^{\circledR}$} & Unexposed & 45.78 & 23.67 & 0.45 & - & 0.67 & 7.45 & 0.15 & 11.98 \\
\hline & Exposed & 47.19 & 28.69 & 0.51 & - & 0.38 & 8.76 & 0.18 & 14.30 \\
\hline \multirow[t]{2}{*}{ G4 Clavulin ${ }^{\circledR}$} & Unexposed & 65.63 & 18.23 & - & 0.27 & 0.46 & 5.74 & 0.16 & 9.51 \\
\hline & Exposed & 53.37 & 24.62 & - & 0.37 & 0.22 & 7.94 & 0.19 & 13.30 \\
\hline \multirow[t]{2}{*}{ G5 Claritin ${ }^{\circledR}$} & Unexposed & 45.89 & 30.12 & 0.50 & 0.21 & 0.27 & 8.82 & 0.15 & 14.05 \\
\hline & Exposed & 44.53 & 29.46 & - & - & 0.28 & 9.63 & 0.26 & 15.84 \\
\hline \multirow[t]{2}{*}{ G6 Polaramine } & Unexposed & 37.94 & 32.29 & - & 0.44 & 2.22 & 10.25 & 0.26 & 16.59 \\
\hline & Exposed & 56.93 & 22.13 & - & - & 0.19 & 7.61 & 0.12 & 13.02 \\
\hline \multirow[t]{2}{*}{ G7 Milli-Q water } & Unexposed & 60.45 & 21.64 & 0.25 & - & 0.40 & 6.54 & 0.13 & 10.59 \\
\hline & Exposed & 47.05 & 28.76 & 0.43 & - & 0.34 & 8.81 & 0.13 & 14.61 \\
\hline
\end{tabular}

-: Chemical element not found.

\section{Discussion}

It is widely known that acidic medicines have certain characteristics, such as low $\mathrm{pH}$, with the potential to produce alterations in the topography of enamel surface. ${ }^{3,4,8,13}$ Many of these medicines, such as antibiotics and antihistamines, are usually used to treat children for long periods. ${ }^{9}$ So, acidic medicines likely promote surface degradation of the tooth and increase dental roughness. Other pediatric medicines (e.g., analgesics) are largely used for children, and even though they are used for short periods, it is also important to evaluate them once they could potentially cause surface alterations. Then, it is important to evaluate the effects of all these medicines chronically or usually used by children, on the topography of dental enamel surface.

For this reason, our selection of medicines was based on previous results ${ }^{8,9,10,11,14}$ as well as on prescriptions for children.

Our study is the first in the searched literature that evaluated changes in surface enamel topography 
with regard to linear $(\mathrm{Ra})$ and volumetric roughness (Sa) and between unexposed and exposed enamel surfaces (Gap). The primary outcome of the present study was the Gap formed between unexposed and exposed enamel surface areas. This parameter was very important to measure the magnitude of tooth structure loss in a direct comparison between unexposed and exposed areas. However, the Ra and Sa parameters were of great importance to determine the topographic alterations in each area. On the other hand, these parameters ( $\mathrm{Ra}$ and $\mathrm{Sa}$ ) cannot be used to compare the Gap.

We observed that the enamel blocks treated with Claritin ${ }^{\circledR}$ presented the worst $\mathrm{Ra}$ and Sa values, demonstrating a greater increase in roughness. Only Claritin ${ }^{\circledR}$ presented significant Gap values. Similar results were observed in previous studies that evaluated the effects of Claritin ${ }^{\circledR}$ on dental enamel. Valinoti et al. ${ }^{10}$ evaluated the effect of three acidic medicines $\left(\right.$ Klaricid $^{\circledR}$, Claritin $^{\circledR}$, and Dimetapp ${ }^{\circledR}$ ) and showed Dimetapp ${ }^{\circledast}$ presented high changes in linear roughness under normal $\mathrm{pH}$-cycling conditions, but Claritin ${ }^{\circledast}$ had the worst linear roughness under erosive $\mathrm{pH}$-cycling conditions. By analyzing SEM images, the authors observed that the specimens exposed to Dimetapp ${ }^{\circledR}$ presented the most severely eroded areas, followed by Claritin ${ }^{\circledast}$. Babu et al. ${ }^{11}$ observed an irregular pattern in SEM, such as the erosion area caused by Claritin ${ }^{\circledast}$. Costa et al. ${ }^{9}$ demonstrated that the group treated with Claritin $\mathrm{D}^{\circledast}$ had significantly lower enamel hardness.

The use of a 3D non-contact profilometer was very advantageous because it does not produce grooves on the surface of the samples and is more sensitive and specific than a roughness tester. ${ }^{15,16,17}$ Non-contact surface profilometry allowed for quantification of tooth depth and its measurements can be compared to those of transverse microradiography (gold standard) for the quantification of enamel changes in vitro. ${ }^{18} \mathrm{No}$ previous investigations had evaluated the action of pediatric medicines on roughness and tooth structure loss using 3D non-contact profilometry.

Salivary buffering and changes in oral $\mathrm{pH}$ are complex, ${ }^{19,20,21}$ and many concomitant factors can influence the potential of substances to promote changes in tooth topography, such as endogenous
$\mathrm{pH}$ lower than 5.5, flow and salivary buffering, and higher titratable acidity. $3,6,8,11,19,21$ Nevertheless, the evaluation of these factors alone cannot determine whether a drug does have such potential., ${ }^{6,20}$

Previous studies ${ }^{1,4,8,11,14,22}$ evaluated various types of medications, taking into consideration their chemical components, $\mathrm{pH}$, or titratable acidity. Some authors observed that Claritin ${ }^{\circledR}$ had low endogenous $\mathrm{pH}$, between 2.1 and $2.8,8,22$ and that Polaramine ${ }^{\circledR}$ presented the highest $\mathrm{pH}$ value (6.0). ${ }^{1}$ Tests using models that may mimic oral conditions are required to evaluate the real action of drugs on tooth structure. ${ }^{23}$ In the literature, there are few studies that test the action of pediatric medicines on teeth under conditions that mimic the oral cavity., ${ }^{9,10,19}$

In our study, we observed that the $\mathrm{pH}$ values of pediatric medicines at room temperature were lower than at cold temperature, and that Claritin ${ }^{\circledR}$ and Alivium ${ }^{\circledR}$ presented the lowest $\mathrm{pH}$ values. We found a difference between $\mathrm{pH}$ values at room and cold temperatures. Since antibiotics could only be used at cold temperatures, the same conditions were utilized for all products. All the pediatric medicines were stored at $7^{\circ} \mathrm{C}$ between treatments and were only removed 5 min before block immersion.

The EDS revealed high rates of carbon, oxygen, phosphorus, and calcium elements in both (exposed and unexposed) areas. However, calcium and phosphorus levels were higher in unexposed than in exposed areas only for the blocks treated with Polaramine ${ }^{\circledR}$. The drug composition itself can interfere with these results; however, this was not evaluated in the present study. The authors suggest that other studies be conducted in order to investigate the composition of these products for a better understanding of the interaction between the ion concentration of the medicines and tooth structure.

In our study, we used two different types of artificial saliva to mimic the change in $\mathrm{pH}$ in the oral cavity. Nonetheless, the results of this in vitro study concerning the effects of liquid pediatric medicines cannot be used for clinical recommendations. Despite the use of $\mathrm{pH}$ cycling with dental elements, in vitro models do not allow properly mimicking all of the events that occur in the oral cavity. ${ }^{21,22,23}$ 
Notwithstanding, our findings are very important for future research, and these preliminary results can contribute to planning new in situ and in vivo studies in order to better understand the effect of the chemical and physical properties of pediatric medicines on enamel topography.

\section{Conclusions}

Most of the pediatric medicines analyzed in this study had a low $\mathrm{pH}$, mainly at room temperature. Claritin $^{\circledR}$, Clavulin ${ }^{\circledR}$, Betamox ${ }^{\circledR}$, and Alivium ${ }^{\circledR}$

\section{References}

1. Neves BG, Farah A, Lucas E, de Sousa VP, Maia LC. Are paediatric medicines risk factors for dental caries and dental erosion? Community Dent Health. 2010 Mar;27(1):46-51.

2. Moazzez R, Bartlett D. Intrinsic causes of erosion. Monogr Oral Sci. 2014 Jun;25:180-96.

3. Hellwig E, Lussi A. Oral hygiene products, medications and drugs - hidden aetiological factors for dental erosion. Monogr Oral Sci. 2014 Jun;25:155-62.

4. Maguire A, Baqir W, Nunn JH. Are sugars-free medicines more erosive than sugars-containing medicines? An in vitro study of paediatric medicines with prolonged oral clearance used regularly and long-term by children. Int J Paediatr Dent. 2007 Jul;17(4):231-8.

5. Linnett V, Seow WK. Dental erosion in children: a literature review. Pediatr Dent. 2001 Jan-Feb;23(1):37-43.

6. Serra MC, Messias DCF, Turssi CP. Control of erosive tooth wear: possibilities and rationale. Braz Oral Res. 2009;23 Suppl 1:49-55.

7. Bartlett DW. The role of erosion in tooth wear: aetiology, prevention and management. Int Dent J. 2005 Aug;55 Suppl 4:277-84.

8. Arora R, Mukherjee U, Arora V. Erosive potential of sugar free and sugar containing pediatric medicines given regularly and long term to children. Indian J Pediatr. 2012 Jun;79(6):759-63.

9. Costa CC, Almeida IC, Costa Filho LC. Erosive effect of an antihistamine-containing syrup on primary enamel and its reduction by fluoride dentifrice. Int J Paediatr Dent. 2006 May;16(3):174-80.

10. Valinoti AC, Pierro VS, Silva EM, Maia LC. In vitro alterations in dental enamel exposed to acidic medicines. Int J Paediatr Dent 2011 Mar;21(2):141-50.

11. Babu KL, Rai K, Hedge AM. Pediatric liquid medicaments--do they erode the teeth surface? An in vitro study: part I. J Clin Pediatr Dent. 2008 Spring;32(3):189-94.

12. Queiroz CS, Hara AT, Paes Leme AF, Cury JA. pH-cycling models to evaluate the effect of low fluoride dentifrice on enamel de- and remineralization. Braz. Dent J. 2008;19(1):21-7. increased linear surface roughness, but only Claritin ${ }^{\circledast}$ demonstrated the in vitro capacity to create significant Gaps between unexposed and exposed enamel surfaces.

\section{Acknowledgments}

The authors acknowledge the financial support from the Coordenação de Aperfeiçoamento de Pessoal de Nível Superior - CAPES, Fundação de Amparo à Pesquisa do Estado do Rio de Janeiro - FAPERJ, and Conselho Nacional de Desenvolvimento Científico e Tecnológico - CNPq.

13. Lodi CS, Sassaki KT, Fraiz FC, Delbem ACB, Martinhon CCR. Evaluation of some properties of fermented milk beverages that affect the demineralization of dental enamel. Braz Oral Res. 2010 Jan-Mar;24(1):95-101.

14. Pierro VS, Abdelnur JP, Maia LC, Trugo LC. Free sugar concentration and $\mathrm{pH}$ of paediatric medicines in Brazil. J Clin Pediatr Dent. 2005 Sep;22(3):180-3.

15. Attin T, Wegehaupt FJ. Methods for assessment of dental erosion. Monogr Oral Sci. 2014 Jun;25:123-42.

16. Attin T, Becker K, Roos M, Attin R, Paque F. Impact of storage conditions on profilometry of eroded dental hard tissue. Clin Oral Investig. 2009 Dec;13(4):473-8.

17. Joniot SB, Gregoire GL, Auther AM, Roques YM. Three-dimensional optical profilometry analysis of surface states obtained after finishing sequences for three composite resins. Oper Dent. 2000 Jul-Aug;25(4):311-5.

18. Elton V, Cooper L, Higham SM, Pender N. Validation of enamel erosion in vitro. J Dent. 2009 May;37(5):336-41.

19. Correa MC, Lerco MM, Cunha Mde L, Henry MA. Salivary parameters and teeth erosions in patients with gastroesophageal reflux disease. Arq Gastroenterol. 2012 Jul-Sep;49(3):214-8.

20. Hellwig E, Lussi A, Goetz F. Influence of Human Saliva on the Development of Artificial Erosion. Caries Res. 2013 Jul;47(6):553-8

21. Hall AF, Buchanan CA, Millett DT, Creanor SL, Strang R, Foye RH. The effect of saliva on enamel and dentine erosion. J Dent. 1999 Jul;27(5):333-9.

22. Xavier AFC, Moura EFF, Azevedo WF, Vieira FF, Abreu MHNG, Cavalcanti AL. Erosive and cariogenicity potential of pediatric drugs: study of physicochemical parameters. BMC Oral Health. 2013 Dec;13:71.

23. Hara AT, Gonzalez-Cabezas C, Creeth J, Zero DT. The effect of human saliva substitutes in an erosion-abrasion cycling model. Eur J Oral Sci. 2008 Dec;116(6):552-6. 